\title{
Quantification of the Influence of Residual Stresses on Fatigue Strength of Al-Alloy Welded Joints by Means of the Local Strain Energy Density Approach
}

\author{
P. Ferro ${ }^{a}$ and F. Berto ${ }^{a, b, 1}$ \\ a Department of Management and Engineering, University of Padova, Vicenza, Italy \\ b Norwegian University of Science and Technology (NTNU), Trondheim, Norway \\ ${ }^{1}$ berto@gest.unipd.it
}

удК 539.4

\section{Количественный анализ влияния остаточных напряжений на усталостную прочность сварных соединений из алюминиевого сплава в рамках подхода локальной плотности энергии деформации}

\author{
П. Ферро ${ }^{\mathrm{a}}$, Ф. Берто ${ }^{\mathrm{a}, \boldsymbol{0}}$ \\ а Факультет менеджмента и инжиниринга, Падуанский университет, Виченца, Италия \\ ${ }^{\sigma}$ Норвежский университет естественных и технических наук, Тронхейм, Норвегия
}

В сварных соединениях в зависимости от граничных условий, параметров сварки и толщуины свариваемых пластин могут наблюдаться высокие сжимающие или растягивающие остаточные напряжения, оказывающие сильное влияние на усталостную прочность в многочикловой области. В случае моделирования стыкового сварного соединения в виде острого V-образного надреза с нулевым радиусом скругления вершины поля остаточных напряжений можно описать с помощью упругих и упругопластических коэффициентов интенсивности остаточных напряжений в надрезе. Это позволяет расчетчикам оченить влияние остаточных напряжений на усталостную долговечность сварных соединений. Проанализировано влияние остаточных напряжений на усталостную прочность стыковых сварных соединений из алюминиевого сплава в рамках подхода локальной плотности энергии деформаџии. Установлена тесная корреляция между полученными расчетными значениями усталостной долговечности и известными экспериментальными данными.

Ключевые слова: локальная плотность энергии деформации, остаточные напряжения, алюминиевый сплав, усталостная долговечность, численное моделирование, сингулярное поле напряжений, коэффициенты интенсивности остаточных напряжений в надрезе.

Introduction. Fatigue resistance of welded joints is highly influenced by residual stresses induced by welding operations, provided the stress ratio is equal to or less than zero and the lives are greater than one million cycles [1,2]. Despite first contradictory results [3-7], which highlighted a poor influence of residual stresses on the fatigue limit of as-welded joints compared to that of the stress-relieved ones, an increase of the fatigue resistance over $150 \%$ was observed in the stress-relieved steel joints [8]. More recent papers, then, confirmed the strong influence of residual stresses on fatigue limit of some types of joints $[9,10]$.

The Design Codes include the residual stresses effect in reference curves obtained by elaborating a large amount of experimental data. Due to the presence of high residual stresses in the real structures, these curves do not depend on the nominal load ratio $(R)$. On 
the other hand, Eurocode 3 allows to increase the category of the welded detail when the welded joints is 'stress-relieved.' In particular, the increment is $33 \%$ when the nominal load ratio changes from $R=0$ to $R=-1$.

In welded joints subjected to fatigue loading, cracks systematically initiate and propagate from the weld toe or weld root where high stress concentration effects are present. If the weld toe region is modeled as a sharp, zero-radius, V-shaped notch, the distribution of the stress in the neighborhood of this zone is linear in a log-log scale and its slope corresponds to the analytical solution by Williams [11], while the intensity of such a stress distribution is quantified by means of the notch stress intensity factor (NSIF) [12]. The idea of estimating the fatigue strength of welded joints on the basis of the stress intensity factor (NSIF) is well established and well documented in the literature [13-18]. However, the calculation of the NSIFs is far from easy if the residual stresses induced by the welding process have to be taken into account. Asymptotic stress fields at the weld toe induced by the solidification of a fusion zone (FZ) in aluminum alloy butt-welded joints were first presented in [19]. In that work, the asymptotic nature of the residual stresses near the weld toe was established and the obtained results were considered a promising starting point for including the residual stress effect on the fatigue strength estimation of welded joints by means of the local approaches mentioned above.

Unfortunately, the strong and complex interaction among thermo-mechanical material properties, clamping conditions, geometry of the workpiece, thermal loads and phase transformation make the calculation of residual stresses very hard and time consuming. A complete solution of such complex problem is possible by using only numerical methods [20]. Reliable models require the implementation of phase transformation effects on the calculation of residual stresses induced by welding [21]. In a previous work, a consistent analysis about the effect of phase transformations on residual stresses induced by a welding operation was carried out [22]. Both volume change and transformation plasticity associated with phase transformations were found to affect the residual stress field. The asymptotic residual stress field near a sharp V-notch tip was investigated in [23, 24]. In those works, authors found that both volume change and transformation plasticity associated with phase transformations have a great influence on the value of the asymptotic residual stress field arising near a V-notch tip. According to the specimen geometry, dimension and shape of the heat affected zone (HAZ), phase transformation effects may change the sign of the singular residual stress field if compared with that calculated with a simplified single-phase material, as usually made in the past.

The main drawback of the local stress approach based on NSIFs is that it does not allow a direct comparison of the fatigue strength of joints having different V-notch opening angle. This is due to rational exponents in the dimensions of NSIFs, whose value varies according to the V-notch opening angle [11]. To overcome this limit, the fatigue strength assessments in the presence of failures from the weld root and the weld toes with different opening angle can be carried out by using energy-based methods such as the $J$-integral approach [25] or by the introduction of the concept of local strain energy density (LSED) over a control volume $[17,26]$.

In a recent work [27], a method to quantify the effects of residual stresses on fatigue strength of welded joints based on the LSED approach was proposed. The method requires an accurate calculation of the asymptotic residual stress field in terms of NSIF and it is applied in the high-cycle regime where the redistribution of residual stresses induced by plastic effects is negligible (small scale yielding hypothesis). However, even if it was shown the capacity of the model to quantify the effect of residual stresses on fatigue strength of welded joints, an appropriate validation by means of experimental data is still not available. The main aim of this work is to fill this gap by taking advantage of some experimental results taken from literature. In particular, data from the work by Bertini et al. [28] were used to validate the proposed method. In that work, the influence of the post weld 
treatments on the fatigue behavior of Al-alloy welded joint was investigated in detail. Published data regarding microhardness profile, residual stresses measurement, and fatigue tests of as-welded and stress-relieved joints were found sufficient for the validation of the proposed method. A good agreement was found between experimental and predicted results. The present paper is threefold. In the first part of the paper the method based on LSED is described showing the main analytical developments. In the second part, the numerical simulations of welding used to calculate the asymptotic residual stress distribution in Al-alloy welded joints are described in detail. Finally, in the third part, the methodology based on LSED is directly applied to estimate the influence of residual stresses on the fatigue strength of as-welded joints.

1. Mathematical Background. Consider the problem of the elastic equilibrium in the presence of a V-shaped notch with an opening angle $2 \beta$ (Fig. 1).

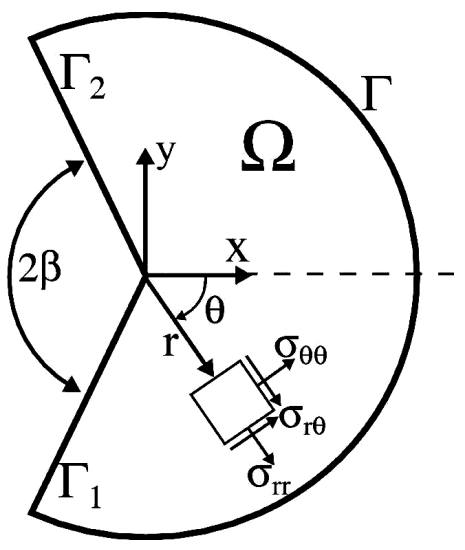

Fig. 1. Domain $\Omega$ for the sharp V-notch problem.

If the material is homogeneous and isotropic, under the hypothesis of linear, thermoelastic theory and plane-strain conditions, it has been demonstrated [19] that the equations representing the stress field near the V-notch, are independent of the thermal terms and match the exact elasto-static solution obtained by Williams [11]. In such conditions, whatever the load applied (thermal or mechanical), under linear-elastic hypothesis and plane-stress or plane-strain conditions, the induced stress field near the notch tip (Fig. 1) (by relating only to the first term of the Williams solution and mode I of V-notch opening), is described by the following asymptotic equation:

$$
\sigma_{i j}(\theta)=\frac{K_{\mathrm{I}}^{t h, m}}{r^{1-\lambda_{\mathrm{I}}}} g_{i j}(\theta) \quad(i, j=r, \theta),
$$

where $g_{i j}(\theta)$ are the angular functions, $\lambda_{\mathrm{I}}$ is the first eigenvalue obtained from Eq. (2),

$$
\lambda \sin (2 \beta)+\sin (2 \beta \lambda)=0,
$$

and $K_{\mathrm{I}}^{t h, m}$ is the NSIF due to a thermal $(t h)$ or mechanical $(m)$ symmetrical load (opening mode I). According to the Gross-Mendelson definition [29]:

$$
K_{\mathrm{I}}^{t h, m}=\sqrt{2 \pi} \lim _{r \rightarrow 0} r^{1-\lambda_{\mathrm{I}}} \sigma_{\theta \theta} \quad(r, \theta=0) .
$$


The first eigenvalue depends only by the V-notch angle $(2 \beta)$ and varies in the range between 0.5 and 1 . The eigenvalue is 0.5 in the crack case $(2 \beta=0)$, and increases to 0.674 and 0.757 when the notch opening angles are equal to 135 and $150^{\circ}$, respectively. Then, the corresponding degrees of singularity of the stress field become 0.5, 0.326, and 0.243.

Since in the linear elastic field the stresses and the strains are linked by the Lame constitutive equations, it is possible to calculate the strain energy density at each point in the vicinity of the notch tip and average it in the control volume near the singular zone.

Under plane strain conditions and mode I loading, the strain energy density averaged in the circular sector of radius $R_{C}$ is $[26,30,31]$ :

$$
\bar{W}=\frac{e_{\mathrm{I}}}{E}\left[\frac{K_{\mathrm{I}}^{t h, m}}{R_{C}^{1-\lambda_{\mathrm{I}}}}\right]^{2},
$$

where the parameter $e_{\mathrm{I}}$ depends on V-notch opening angle $(2 \beta)$, Poisson's ratio $(v)$ of the material and failure hypothesis. Under Beltrami failure hypothesis (total strain energy density) and plane strain conditions, $v=0.34$ (aluminum alloy AA 6063) and $2 \beta=135^{\circ}$, $e_{\mathrm{I}}$ is equal to 0.111 . The control radius $\left(R_{C}\right)$ is a material characteristic length that for Al-alloy welded joints was found to be equal to $0.12 \mathrm{~mm}[17,30]$. For more details and application of the SED approach see, e.g., [32-36].

Relating to fatigue problems of welded joints, $K_{\mathrm{I}}^{m}$ [Eq. (4)] is normally the NSIF of as-welded joints, which would take also into account the presence of pre-existing residual stresses. However, due to the lacking of information about the residual stress field near the weld toe induced by welding processes, the contribution due to the residual stress has been always neglected in the past. Residual stresses have the effect of modifying the local load ratio $(R)$. As a matter of fact, the following relationships can be written:

$$
\begin{aligned}
& \Delta K=K_{\mathrm{I}_{\max }}^{m}-K_{\mathrm{I}_{\min }}^{m} \\
& \left.\begin{array}{l}
R=\frac{K_{\mathrm{I}_{\text {min }}}^{m}+K_{\mathrm{I}}^{\text {res }}}{K_{\mathrm{I}_{\max }}^{L}+K_{\mathrm{I}}^{\text {res }}} \\
R^{m}=K_{\mathrm{I}_{\min }}^{m} / K_{\mathrm{I}_{\max }^{m}}^{m}
\end{array}\right\} \quad K_{\mathrm{I}_{\text {min }}}^{m}+K_{\mathrm{I}}^{\text {res }}>0, \\
& \left.\begin{array}{l}
\Delta K=K_{\mathrm{I}_{\max }}^{m}+K_{\mathrm{I}}^{r e s} \\
R=0
\end{array}\right\} \quad K_{\mathrm{I}_{\min }^{m}}^{m}+K_{\mathrm{I}}^{r e s} \leq 0,
\end{aligned}
$$

where now $K_{\mathrm{I}}^{\text {res }}$ is the $R$-NSIF which characterizes the residual stress field, and $R^{m}$ and $R$ correspond to the local load ratio of the nominal and real cycle, respectively.

Starting from Eqs. (4)-(6), for $R=0$, the following equation is obtained (details about the analytical frame employed are published in [27]):

$$
\Delta \sigma_{n}=\frac{R_{C}^{1-\lambda_{\mathrm{I}}}\left(\frac{E}{e_{\mathrm{I}}}\left(\frac{C}{N}\right)^{1 / z}\right)^{1 / 2}}{k_{\mathrm{I}} h^{1-\lambda_{\mathrm{I}}}}-\frac{K_{\mathrm{I}}^{\text {res }}}{k_{\mathrm{I}} h^{1-\lambda_{\mathrm{I}}}},
$$

where $\Delta \sigma_{n}$ is the nominal stress range. Similarly, for $R>0$ the following relationship is obtained: 


$$
\sigma_{\max }^{L}=\frac{\left(\left(K_{\mathrm{I}}^{r e s}\right)^{2}+\frac{\left(1+R^{m}\right) E}{\left(1-R^{m}\right) e_{\mathrm{I}}} R_{C}^{2\left(1-\lambda_{\mathrm{I}}\right)}\left(\frac{C}{N}\right)^{1 / z}\right)^{1 / 2}}{k_{\mathrm{I}} t^{1-\lambda_{\mathrm{I}}}\left(1+R^{m}\right)}-\frac{K_{\mathrm{I}}^{r e s}}{k_{\mathrm{I}} t^{1-\lambda_{\mathrm{I}}}\left(1+R^{m}\right)},
$$

where $C$ is a constant and $z$ is the slope of the fatigue data expressed in terms of local strain energy density experimentally calculated $\left(z=\log \left(N_{D_{1}} / N_{D_{2}}\right) / \log \left(\Delta \bar{W}_{D_{2}} / \Delta \bar{W}_{D_{1}}\right)\right)$, subscripts $D_{1}$ and $D_{2}$ indicate two points of the curve $\Delta \bar{W}(N), k_{\mathrm{I}}$ is a non-dimensional coefficient, similar to the shape functions of cracked components calculated by using the following equation:

$$
K_{\mathrm{I}}^{m}=k_{\mathrm{I}} \sigma_{n} h^{1-\lambda_{\mathrm{I}}}
$$

where $\sigma_{n}$ is the remotely applied stress, and $h$ is a geometrical parameter of the plate, according to Lazzarin and Tovo [12]. Equations (7) and (8) are applied in high-cycle fatigue regime where the redistribution of the pre-existing residual stresses are considered negligible [27].

2. Numerical Welding Simulation. By using the experimental data found in [28], 6063 Al-alloy sheets welding was simulated by means of Sysweld ${ }^{\circledR}$ numerical code. Plates were welded in the double V-configuration using the GMAW technique and the ER4043 alloy as filler metal. Geometry of the specimens is shown in Fig. 2. The weld toe is modelled as a sharp V-notch with $2 \beta=135^{\circ}$.

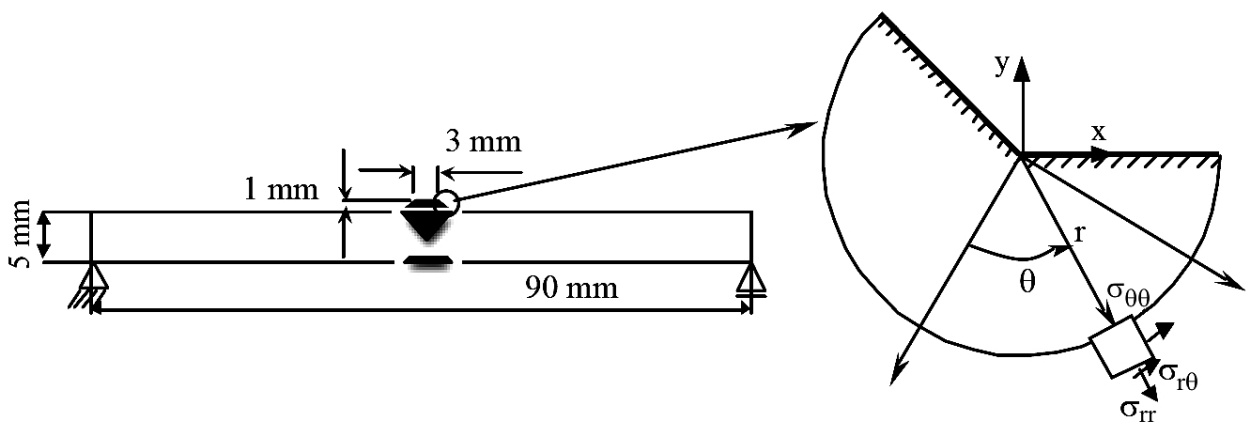

Fig. 2. Schematic representation of cross sectional area of the butt-welded joint and polar coordinate system centred on the singular point. $\left(\mathrm{V}\right.$-notch angle $=135^{\circ}$.)

The V-notch angle was chosen on the basis of several analyses of aluminum welded joints [17] and the geometry of the numerical model provided in [28].

Thermo-mechanical materials properties of the base metal were taken from Sysweld $\mathbb{}$ database. The dependence of thermal properties with respect to the temperature was found not to have a significant influence on temperature and residual-stress distributions [37-39]. Here, for the sake of simplicity, room temperature thermal properties were employed (see Table 1) [37-39]; on the other hand, residual-stress distributions are strongly dependent on the variation of the mechanical properties with temperature, so that the yield stress range was taken into account [37-39]. In this work, the isotropic strain-hardening model is used and true stress-strain curve of the welded metal (ER4043) is taken from [40] where data from microtraction tests are available.

In order to simulate the softening effect induced by welding in the HAZ, dissolution of $\beta^{\prime \prime}\left(\mathrm{Mg}_{2} \mathrm{Si}\right)$ precipitates is taken into account by means of the following reversion model [41]: 


$$
f=\left(\frac{t}{t_{r}^{*}}\right) \exp \left[\left(\frac{Q_{s}}{R^{g}}+\frac{n Q_{d}}{R^{g}}\right)\left(\frac{1}{T_{r}}+\frac{1}{T}\right)\right],
$$

where $f$ is the dissolution fraction of precipitates, $t$ is the time, $T$ is the temperature $(\mathrm{K})$, $R^{g}$ is the constant of a perfect gas, $t_{r}^{*}(900 \mathrm{~s})$ is the time necessary for the total dissolution of precipitates at a given temperature $T_{r}\left(330^{\circ} \mathrm{C}\right), Q_{s}$ is the enthalpy of metastable solvus (434.6 J/mol), $Q_{d}$ is the energy for activation of diffusion process of one of alloy elements (the less mobile) $(1883.8 \mathrm{~J} / \mathrm{mol})$ and, finally, $n$ is a parameter which depends on $f[n(f)=$ $=0.5-a f^{b}$, with $a=0.3948$ and $\left.b=0.2669\right)$. The values of parameters in Eq. (10) were taken from the Sysweld ${ }^{\circledR}$ database. The yield stress in the HAZ has been calculated by using the following linear mixture law:

$$
\sigma_{Y}=f \sigma_{Y}^{S H T}+(1-f) \sigma_{Y}^{T 6}
$$

where $\sigma_{Y}^{S H T}$ and $\sigma_{Y}^{T 6}$ are the yield stresses of the material at solution heat treated (SHT) and T6 condition (solution heat treated and then artificially aged), respectively. Due to the great number of nodes necessary to capture the asymptotic stress field near the weld toe, a 2D model under generalized plane-strain conditions has been used (for more details about the use of 2D models for the welding process simulation, see [42-44]).

By taking advantage of the double symmetry, only one half of the joint was modelled and analysed with about 5500 parabolic isoparametric elements (Fig. 3). At the notch tip, the minimum size of the elements was about $5 \cdot 10^{-4} \mathrm{~mm}$. Finally, an uncoupled, thermomechanical analysis was carried out. The mesh was fitted only in the bottom side of the joint where tensile stresses were applied during the four-point bending fatigue test. Preliminary analyses have shown that the $R$-NSIF $\left(K_{\mathrm{I}}^{\text {res }}\right)$ in both sides of the joint is negative but it is higher (in absolute value) in the bottom side compared to the top side.

T a b 1 e 1

Thermal Properties of Aluminum Alloy AA-6063 at Room Temperature

\begin{tabular}{|c|c|c|c|}
\hline $\begin{array}{c}\text { Thermal conductivity } \\
(\mathrm{W} /(\mathrm{m} \cdot \mathrm{K}))\end{array}$ & $\begin{array}{c}\text { Thermal capacity } \\
\left(\mathrm{J} /\left(\mathrm{kg} \cdot{ }^{\circ} \mathrm{C}\right)\right)\end{array}$ & $\begin{array}{c}\text { Density } \\
\left(\mathrm{kg} / \mathrm{m}^{3}\right)\end{array}$ & $\begin{array}{c}\text { Solidus temperature } \\
\left({ }^{\circ} \mathrm{C}\right)\end{array}$ \\
\hline 200 & 900 & 2700 & 616 \\
\hline
\end{tabular}

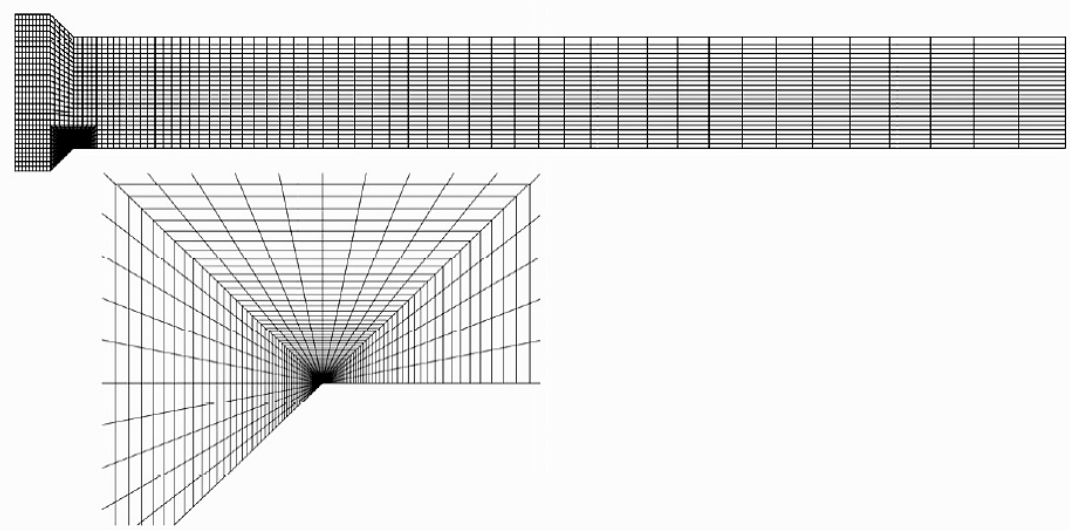

Fig. 3. FE mesh of the specimen. 
The two-pass arc welding process was simulated by means of Goldak's source [45] shown in Fig. 4. By using the original symbols present in Goldak's paper, the heat source is described for a $2 \mathrm{D}$ model by the following equation:

$$
q_{g}(x, y, t)=\frac{6 \sqrt{3} f_{1,2} Q}{\pi \sqrt{\pi} a b c_{1,2}} e^{-3 x^{2} / a^{2}} e^{-3 y^{2} / b^{2}} e^{-3[v(\tau-t)]^{2} / c_{1,2}} .
$$

The meaning of symbols in Eq. (12) and their values are summarized in Table 2.

$\mathrm{T}$ a b 1 e 2

\section{Goldak's Source Parameters}

\begin{tabular}{|c|c|c|}
\hline$Q^{*}$ & Power input $[\mathrm{W}]$ & 2860 \\
\hline$\eta$ & Efficiency & 0.64 \\
\hline$Q$ & Absorbed power [W], with $Q=\eta Q^{*}$ & 1830 \\
\hline$a$ & \multirow{4}{*}{ Molten pool dimensions $[\mathrm{mm}]$} & 4.0 \\
\hline$b$ & & 1.5 \\
\hline$c_{1}$ & & 2.3 \\
\hline$c_{2}$ & & 7.9 \\
\hline$f_{1}$ & \multirow{2}{*}{ Constants for the energy distribution of the heat flux } & 0.6 \\
\hline$f_{2}$ & & 1.4 \\
\hline$v$ & Welding speed $[\mathrm{mm} / \mathrm{s}]$ & 11 \\
\hline$\tau$ & $\begin{array}{l}\text { Total time spent by the welding source to be over the transverse cross } \\
\text { section of the plate [s] }\end{array}$ & 35 \\
\hline
\end{tabular}

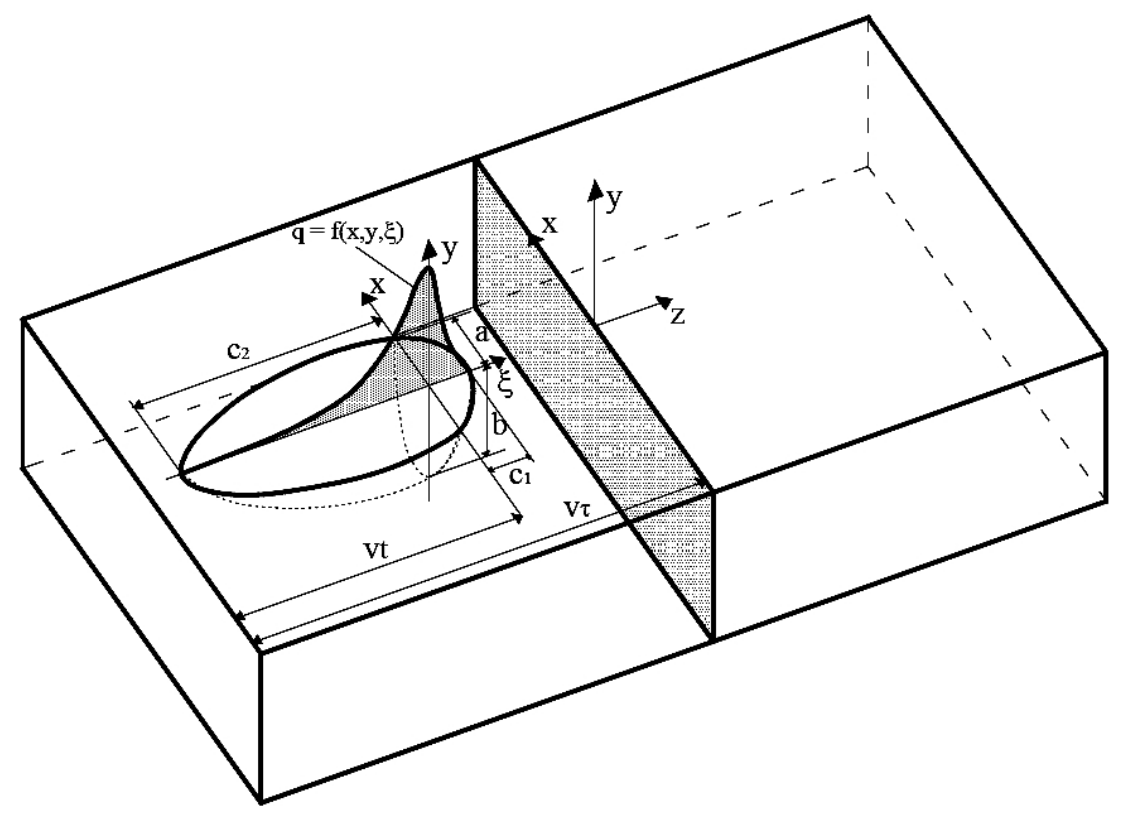

Fig. 4. Two double ellipsoid heat sources configuration together with the power distribution function along the $\xi$ axis of the moving coordinate system $(x, y, \xi)$. The transformation relating the fixed and moving coordinate system is $\xi=z+v(\tau-t)$. 
Due to the absence of information about the source parameters used in [28], a calibration was possible by using the microhardness profile published in that work. As a matter of fact, the hardness near the weld bead is a function of the thermal and metallurgical history induced by the welding source in that zone. The microhardness profile has been estimated by using the following linear mixture law:

$$
H V=f H V^{S H T}+(1-f) H V^{T 6},
$$

where $H V^{T 6}$ and $H V^{S H T}$ are the Vickers hardness of the material in the T6 $(85 \mathrm{HV})$ and solution heat treated $(50 \mathrm{HV})$ condition, respectively. Finally, fusion zones were modelled by element birth method.

3. Results and Discussion. Figure 5 shows the comparison between the experimental and numerical microhardness, together with the peak temperature $\left(T_{p}\right)$, as a function of the distance from the fusion line. Figure 5 is the result of the welding parameters calibration (Table 2) obtained by means of different numerical simulations. A good correlation can be observed between the calculated and measured HAZ extension. Discrepancies in the microhardness numerical and experimental values for distances less then $4 \mathrm{~mm}$ (where the minimum hardness value was measured), are due to the effect of natural ageing [41], not taken into account here for sake of simplicity.

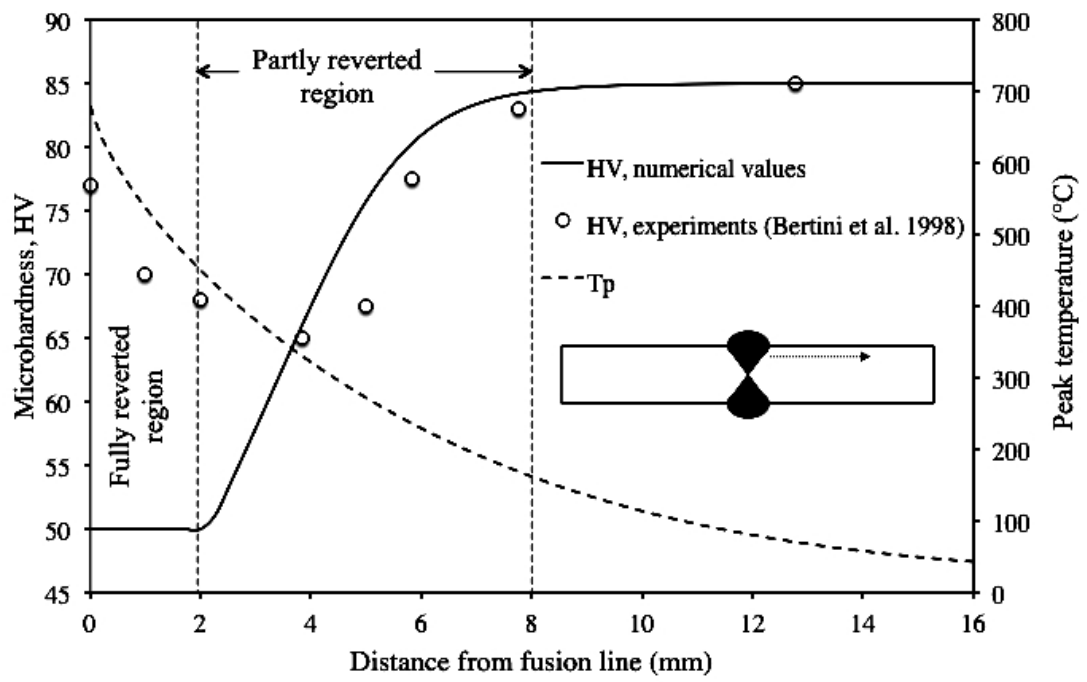

Fig. 5. Numerical and experimental microhardness profiles and peak temperature $T_{p}$ as a function of the distance from the notch tip.

Figure 6 shows the distribution of phase $f$ (corresponding to the aluminum alloy at the solution heat treated state) at room temperature and the temperature distribution at the instant of maximum FZ extension.

The asymptotic distribution of residual stresses near the weld toe of the bottom side of the joint is shown in Fig. 7 (since negative residual stresses were calculated, their absolute value is plotted in the log-log diagram). A good correlation is found between the numerical and analytical elastic solution [see Eq. (1)]. Due to the mixed mode loading, the analytical solution contains also the mode II component that is not singular for the analysed V-notch opening angle. However, the first term (mode I) dominates up to about $0.15 \mathrm{~mm}$ from the notch. Since the $R_{c}$ value for aluminum alloys welded joints is $0.12 \mathrm{~mm}$ [17], the use of only the first term (mode I) for the calculation of the strain energy density [see Eq. (4)] is 


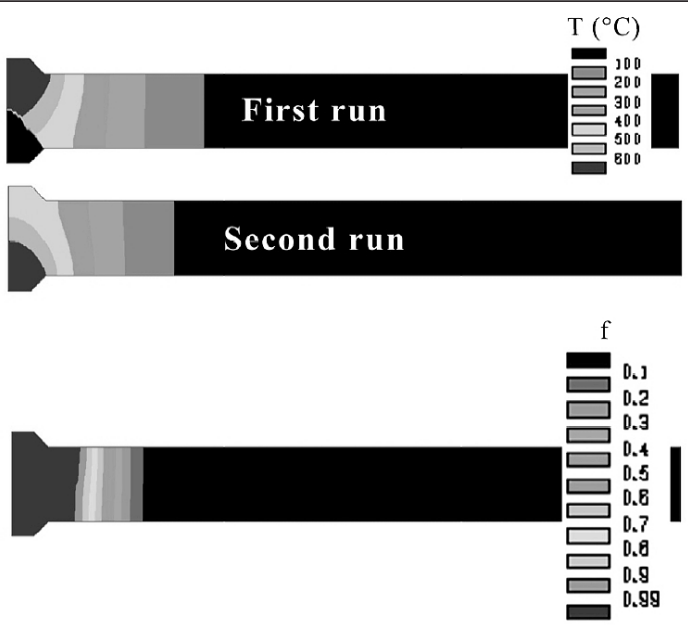

Fig. 6. Fraction $f$ of completely dissolved precipitates at room temperature and temperature distribution at the instants of maximum FZ extension.

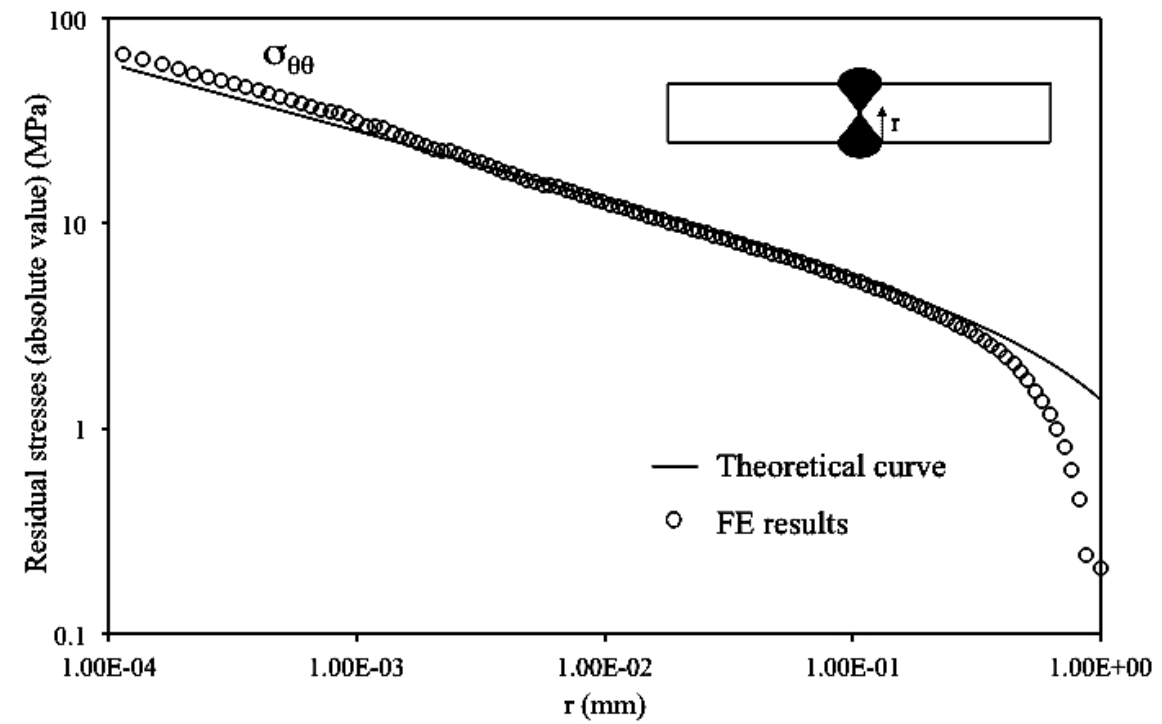

Fig. 7. Absolute value of the residual stress distribution $(\theta \theta$ component $)$ at $\theta=22.5^{\circ}\left(K_{\mathrm{I}}^{\text {res }}=\right.$ $\left.=-8.3 \mathrm{MPa} \cdot \mathrm{mm}^{0.3264}, K_{\mathrm{II}}^{\text {res }}=5 \mathrm{MPa} \cdot \mathrm{mm}^{-0.3021}\right)$.

fully justified. In particular, the intensity of the asymptotic residual stress field is expressed by a value of $K_{\mathrm{I}}^{\text {res }}$ equal to $-8.3 \mathrm{MPa} \cdot \mathrm{mm}^{0.3264}$.

Now, by using the plate thickness $(5 \mathrm{~mm})$ as reference dimension $(h), k_{\mathrm{I}}$ [see Eq. (9)] is easily found to be equal to 0.976 . Fatigue data of stress-relieved samples published in [28] are used to calculate the fatigue curve expressed in terms of local strain energy density by means of Eq. (7) with $K_{I}^{\text {res }}$ equal to 0 . Results obtained are collected in Table 3.

Finally, by using Eq. (7) with $K_{\mathrm{I}}^{\text {res }}$ equal to $-8.3 \mathrm{MPa} \cdot \mathrm{mm}^{0.3264}$, the influence of residual stresses on fatigue strength of welded joints has been estimated. Figure 8 shows the fatigue curves of stress-relieved and as-welded joints with a comparison between the experimental and predicted results obtained with the proposed method. The correlation between predicted and experimental results can be considered good in the high-cycle 
regime where the redistribution of residual stresses induced by local plastic deformation can be neglected. However, it is clearly seen that in the short life region the experimental curves overlap due to the redistribution of residual stresses induced by local plastic deformation, as demonstrated in a previous work [27]. It is useful to observe that cracks were always observed to nucleate at the weld root [28] were the local strain energy density has been calculated.

$\mathrm{T}$ a b 1 e 3

Fatigue Curve Parameters Expressed in Terms of Local Strain Energy Density

\begin{tabular}{|c|c|c||}
\hline Life region & $z$ & $C, \mathrm{MPa}^{z}$ \\
\hline Short life region & 2.275 & 4470 \\
\hline $\begin{array}{c}\text { Long life region } \\
\text { from } 2 \cdot 10^{6} \text { cycles) }\end{array}$ & 8.5 & $2.41 \cdot 10^{-4}$ \\
\hline
\end{tabular}

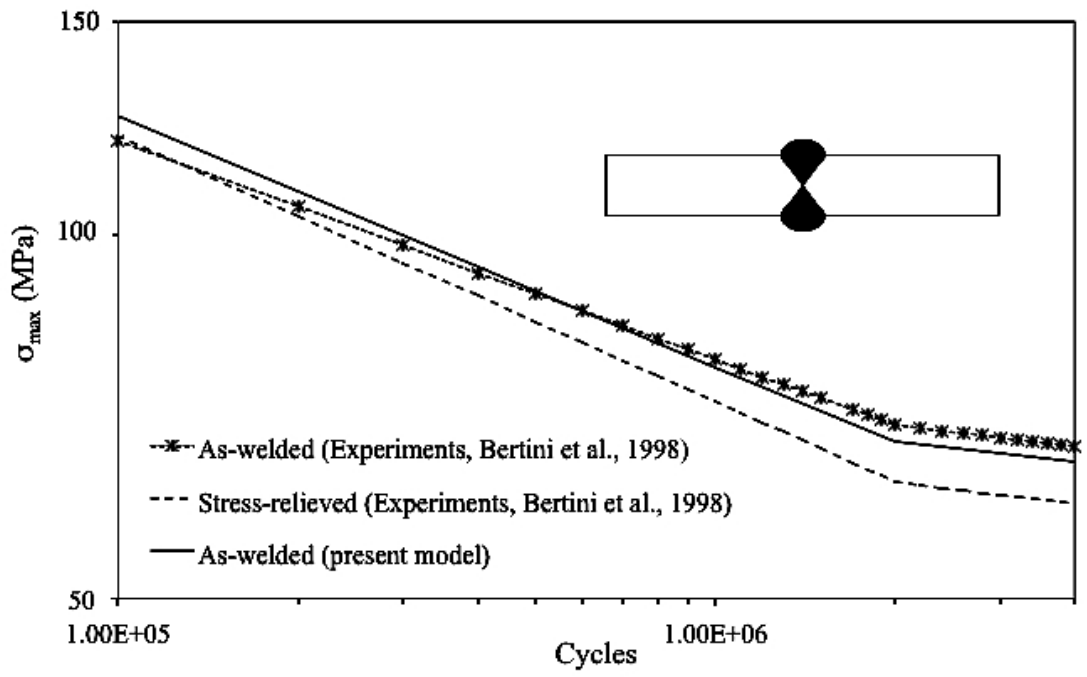

Fig. 8. Comparison between the P50 fatigue curves of as-welded and stress-relieved joints.

Finally, it is worth mentioning that in real welded joints, a coupled effect arises among modes I, II, and III, which can be captured only by means of 3D models [46, 47]. A model improvement should thus be expected by means of $3 \mathrm{D}$ numerical welding simulations. It is also important to underline that the present paper refers to traditional arc-welding process and the critical radius should be re-calculated if laser beam welding [48] is considered.

\section{Conclusions}

1. An attempt was made to validate a recent model based on LSDE approach that estimates the influence of residual stress on fatigue strength of welded joints. Experimental results about fatigue strength of Al-alloy welded joints were taken from literature.

2. The proposed method requires an accurate calculation of the asymptotic residual stress field in terms of NSIFs and it is applied in the high-cycle regime where the redistribution of residual stress induced by plastic effects is negligible (small scale yielding hypothesis).

3. By using information from microhardness profile across the HAZ, the source parameters were calibrated. 
Quantification of the Influence of Residual Stresses on Fatigue Strength ...

4. The calculated asymptotic residual stress field showed a good correlation with the elastic solution by Williams. In particular, a negative value of the R-NSIF was found. An improvement of fatigue strength is thus expected for the as-welded joints compared to the stress-relieved ones.

5. Fatigue curves predicted by the model confirmed this phenomenon and showed a good correlation with experimental fatigue tests. This can be considered a good starting point for further validations of the model by using experimental data related also to steel welded joints and more accurate 3D numerical analyses.

\section{Резюме}

У зварних з'єднаннях у залежності від граничних умов, параметрів зварювання і товщини зварюваних пластин можуть мати місце високі стискальні або розтяжні залишкові напруження, які мають сильний вплив на міцність від утомленості у багатоцикловій області. При моделюванні стикового зварного з'єднання у вигляді гострого V-подібного надрізу з нульовим радіусом скруглення вершини поля залишкових напружень можна описати за допомогою пружних і пружно-пластичних коефіцієнтів інтенсивності залишкових напружень у надрізі. Це дозволяє розраховувачам оцінити вплив залишкових напружень на утомну довговічність зварних з'єднань. Проаналізовано вплив залишкових напружень на міцність від утомленості стикових зварних з'єднань з алюмінієвого сплаву в рамках підходу локальної щільності енергії деформації. Установлено тісну кореляцію між отриманими розрахунковими значеннями утомної довговічності та відомими експериментальними даними.

1. J. F. Throop and H. S. Reemsnyder, Residual Stress Effects in Fatigue, ASTM STP 776 (1981).

2. T. R. Gurney, Fatigue of Welded Structures, Cambridge University Press, Cambridge, UK (1979).

3. M. Ross, "Experiments for the determination of the influence of residual stresses on the fatigue strength of structures," Weld. Res. BWRA, 4, No. 5, 83-93 (1950).

4. W. Soete and R. van Crombrugge, "A study of the fatigue strength of welded joints," Rev. Soudure Lastijdscrift, 2 (1950).

5. W. Soete and R. van Crombrugge, "A study of the fatigue strength of welded joints," Rev. Soudure Lastijdscrift, 4 (1950).

6. W. Soete and R. van Crombrugge, "A study of the fatigue strength of welded joints," Rev. Soudure Lastijdscrift, 2 (1951).

7. W. M. Wilson and A. B. Wilder, Fatigue Tests of Butt Welds in Structural Steel Plates, Bulletin No. 310, University of Illinois Engineering Experiment Station (1939).

8. I. V. Kudryavstev, "The influence of internal stresses on the fatigue endurance of steel," in: Proc. of the IMechE Conf. on Fatigue, Institution of Mechanical Engineers, London (1956), pp. 317-325.

9. V. I. Trufyakov, "Welded joints and residual stresses," Avtomat. Svarka, No. 5, 90-103 (1956).

10. V. I. Trufyakov, "Welded joints and residual stresses," Br. Weld. J., 5, No. 11, 491-498 (1958).

11. M. L. Williams, "Stress singularities resulting from various boundary conditions in angular corners of plates in extension," J. Appl. Mech., 19, No. 4, 526-528 (1952). 
12. P. Lazzarin and R. Tovo, "A notch intensity factor approach to the stress analysis of welds," Fatigue Fract. Eng. Mater. Struct., 21, 1089-1103 (1998).

13. T. Boukharouba, T. Tamine, L. Nui, et al., "The use of notch stress intensity factor as a fatigue crack initiation parameter," Eng. Fract. Mech., 52, 503-512 (1995).

14. Y. Verreman and B. Nie, "Early development of fatigue cracking at manual fillet welds," Fatigue Fract. Eng. Mater. Struct., 19, 669-681 (1996).

15. B. Atzori, P. Lazzarin, and R. Tovo, "From a local stress approach to fracture mechanics: a comprehensive evaluation of the fatigue strength of welded joints," Fatigue Fract. Eng. Mater. Struct., 22, 369-381 (1999).

16. P. Lazzarin and P. Livieri, "Notch stress intensity factors and fatigue strength of aluminium and steel welded joints," Int. J. Fatigue, 23, 225-232 (2001).

17. P. Livieri and P Lazzarin, "Fatigue strength of steel and aluminium welded joints based on generalised stress intensity factors and local strain energy values," Int. J. Fract., 133, 247-276 (2005).

18. D. Radaj, "State-of-the-art review on extended stress intensity factor concepts," Fatigue Fract. Eng. Mater. Struct., 37, 1-28 (2014).

19. P. Ferro, F. Berto, and P. Lazzarin, "Generalized stress intensity factors due to steady and transient thermal loads with applications to welded joints," Fatigue Fract. Eng. Mater. Struct., 29, 440-453 (2006).

20. A. Anca, A. Cardona, J. Risso, and V. D. Fachinotti, "Finite element modeling of welding processes," Appl. Math. Model., 35, 688-707 (2011).

21. P. Ferro, F. Bonollo, and A. Tiziani, "Methodologies and experimental validations of welding process numerical simulation," Int. J. Comput. Mater. Sci. Surf. Eng., 3, 114-132 (2010).

22. P. Ferro, H. Porzner, A. Tiziani, and F. Bonollo, "The influence of phase transformation on residual stresses induced by the welding process - 3D and 2D numerical models," Model. Simul. Mater. Sci. Eng., 14, 117-136 (2006).

23. P. Ferro and N. Petrone, "Asymptotic thermal and residual stress distribution due to transient thermal loads," Fatigue Fract. Eng. Mater. Struct., 32, 936-948 (2009).

24. P. Ferro, "Influence of phase transformations on the asymptotic residual stress distribution arising near a sharp V-notch tip," Model. Simul. Mater. Sci. Eng., 20, 085003 (2012), doi:10.1088/0965-0393/20/8/085003.

25. D. Frank, J. Romanoff, and H. Remes, "Fatigue strength assessment of laser stakewelded web-core steel sandwich panels," Fatigue Fract. Eng. Mater. Struct., 36, 724-737 (2013).

26. P. Lazzarin and R. Zambardi, "A finite-volume-energy based approach to predict the static and fatigue behavior of components with sharp V-shaped notches," Int. J. Fract., 112, 275-298 (2001).

27. P. Ferro, "The local strain energy density approach applied to pre-stressed components subject to cyclic load," Fatigue Fract. Eng. Mater. Struct., 37, 1268-1280 (2014).

28. L. Bertini, V. Fontanari and G. Straffellini, "Influence of post weld treatments on fatigue behaviour of Al-alloy welded joints," Int. J. Fatigue, 20, 749-755 (1998).

29. R. Gross and A. Mendelson, "Plane elastoplastic analysis of V-notched plates," Int. J. Fract. Mech., 8, 267-276 (1972).

30. F. Berto and P. Lazzarin, "A review of the volume-based strain energy density approach applied to V-notches and welded structures," Theor. Appl. Fract. Mech., 52, 183-194 (2009). 
31. F. Berto and P. Lazzarin, "Fatigue strength of structural components under multi-axial loading in terms of local energy density averaged on a control volume," Int. J. Fatigue, 33, 1055-1065 (2011).

32. F. Berto, P. Lazzarin, and C. Marangon, "Fatigue strength of notched specimens made of 40CrMoV13.9 under multiaxial loading," Mater. Des., 54, 57-66 (2014).

33. F. Berto, A. Campagnolo, and P. Lazzarin, "Fatigue strength of severely notched specimens made of Ti-6Al-4V under multiaxial loading," Fatigue Fract. Eng. Mater. Struct., 38, 503-517 (2015), doi:10.1111/ffe.12272.

34. F. Berto, P. Gallo, and P. Lazzarin, "High temperature fatigue tests of un-notched and notched specimens made of 40CrMoV13.9 steel," Mater. Des., 63, 609-619 (2014).

35. F. Berto and P. Lazzarin, "Recent developments in brittle and quasi-brittle failure assessment of engineering materials by means of local approaches," Mater. Sci. Eng. $R$ Reports, 75, 1-48 (2014).

36. P. Lazzarin, A. Campagnolo, and F. Berto, "A comparison among some recent energy- and stress-based criteria for the fracture assessment of sharp V-notched components under Mode I loading," Theor. Appl. Fract. Mech., 71, 21-30 (2014).

37. X. K. Zhu and Y. J. Chao, "Effects of temperature-dependent material properties on welding simulation," Comput. Struct., 80, 967-976 (2002).

38. A. Barroso, J. Canas, R. Picon, et al., "Prediction of welding residual stresses and displacements by simplified models. Experimental validation," Mater. Des., 31, 13381349 (2010).

39. A. Bhatti Ayjwat, Z. Barsoun, H. Murakawa, and I. Barsoum, "Influence of thermomechanical material properties of different steel grades on welding residual stresses and angular distortion," Mater. Des., 65, 878-889 (2015).

40. W. A. Monteiro (Ed.), Light Metal Alloys Applications, Ch. 2: R. R. Ambriz and D. Jaramillo, Mechanical Behavior of Precipitation Hardened Aluminum Alloys Welds, InTech (2014), ISBN: 978-953-51-1588-5, doi: 10.5772/58418.

41. Ø. Grong, Metallurgical Modelling of Welding, 2nd edn, Cambridge University Press, Cambridge, UK (1997).

42. D. H. B. Mok and R. J. Pick, "Finite element study of residual stresses in a plate T-joint fatigue specimen," Int. J. Fatigue, 13, 281-291 (1991).

43. S. Sarkani, V. Tritchkov, and G. Michaelov, "An efficient approach for computing residual stresses in welded joints," Finite Elem. Anal. Des., 35, 247-268 (2000).

44. T. L. Teng, C. P. Fung, P. H. Chang, and W. C. Yang, "Analysis of residual stresses and distortions in T-joint fillet welds," Int. J. Press. Vess. Piping, 78, 523-538 (2001).

45. J. Goldak, A. Chakravarti, and M. Birbby, "A new finite element model for welding heat sources," Metall. Trans. B, 15, 299-305 (1984).

46. L. P. Pook, "A 50-year retrospective review of three-dimensional effects at cracks and sharp notches," Fatigue Fract. Eng. Mater. Struct., 36, 699-723 (2013).

47. P. Lazzarin, M. Zappalorto, and F. Berto, "Three-dimensional stress fields due to notches in plates under linear elastic and elastic-plastic conditions," Fatigue Fract. Eng. Mater. Struct., 38, 140-153 (2013), doi: 10.1111/ffe.12138.

48. G. Mi, X. Zhan, Y. Wei, et al., "A thermal-metallurgical model of laser beam welding simulation for carbon steels," Model. Simul. Mater. Sci. Eng., 23, 035010 (2015), doi: 10.1088/0965-0393/23/3/035010. 